\title{
FRUIT SELF-SUFFICIENCY ASSESSMENT IN BOSNIA AND HERZEGOVINA
}

\section{Aleksandar Ostojić ${ }^{1}, \check{Z ̌ e l j k o ~ V a s ̌ k o}^{2}$, Miljan Cvetković ${ }^{3}$, Boris Pašalićc}

\begin{abstract}
Fruit is one of the essential products in the proper nutrition of the population. In the conditions of free trade, due to the great economic importance of fruits and fruit products, fruit foreign trade is subject to constant monitoring and evaluation of the production and consumption conformity. The aim of this paper is to analyze the volume, dynamics and structure of fruit production and consumption in Bosnia and Herzegovina $(\mathrm{BiH})$ in the period 2014-2017, and point to the need for greater alignment of fruit production and consumption. Data from secondary sources were studied to determine the degree of self-sufficiency for apples, pears and plums, the three main fruit species in Bosnia and Herzegovina. Methodologically, the level of self-sufficiency was calculated using formulas recommended by FAO and the Laspeyres aggregated price index. The degree of self-sufficiency in apple is between $70 \%$ and $86 \%$, depending on the year. Pear has the lowest production but slightly higher degree of self-sufficiency compared to apple (88-96\%). BiH has a surplus only in plum, in both fresh plums and plum products, which means that the degree of self-sufficiency is higher than $100 \%$ by $2-5 \%$. Given its geographical location and climatic conditions, $\mathrm{BiH}$ could produce more fruit than its current production, fully meet the needs of its population, and generate a surplus in its foreign trade.
\end{abstract}

Key words: fruit, self-sufficiency, consumption, production, import, export.

JEL'5: D57, F14

1 Aleksandar Ostojić, Ph.D., Full Professor, University of Banja Luka, Faculty of Agriculture, Bulevar vojvode Petra Bojović 1A, 78000 Banja Luka, Republic of Srpska, Bosnia and Herzegovina, Phone: +387 51330 926, E-mail: aleksandar.ostojic@agro.unibl.org

2 Željko Vaško, Ph.D., Full Professor, University of Banja Luka, Faculty of Agriculture, Bulevar vojvode Petra Bojović 1A, 78000 Banja Luka, Republic of Srpska, Bosnia and Herzegovina, Phone: +387 51330 929, E-mail: zeliko.vasko@agro.unibl.org

3 Miljan Cvetković, Ph.D., Associate Professor, University of Banja Luka, Faculty of Agriculture, Bulevar vojvode Petra Bojović 1A, 78000 Banja Luka, Republic of Srpska, Bosnia and Herzegovina, Phone: +387 51330 938, E-mail: miljan.cvetkovic@agro.unibl.org

4 Boris Pašalić, Ph.D., Associate Professor, University of Banja Luka, Faculty of Agriculture, Bulevar vojvode Petra Bojović 1A, 78000 Banja Luka, Republic of Srpska, Bosnia and Herzegovina, Phone: +387 51330 936, E-mail: boris.pasalic@agro.unibl.org

5 Article info: Review Article, Received: $12^{\text {th }}$ November 2019., Accepted: $25^{\text {th }}$ November 2019. 


\section{Introduction}

Each country prefers to reach the goal of self-sufficiency in the production of certain agricultural products, if they have favorable production conditions. According to the FAO, the concept of food self-sufficiency "is generally taken to mean the extent to which a country can meet its food needs from its own domestic production" (Thomson, Metz, 1998). The pursuit of self-sufficiency is an opposition to free trade and critics of the achieving self-sufficiency consider it a threat to achieving economic efficiency in food production (Clapp, 2017). However, regardless of orientation (liberalism or protectionism), most countries in the world are engaged in establishing a level of a certain level of self-sufficiency, especially for main food products. That also apples to Bosnia and Herzegovina, a country that is a net food importer in which a significant amount of foreign exchange is spent to cover the foreign trade deficit of 7.08 billion KM (Convertible Mark, currency of BiH) in 2017 (MOFTER, 2018). Although achieving greater self-sufficiency in food consumption is not formally a strategic goal of the agricultural sector development in $\mathrm{BiH}$, the foreign trade deficit in agricultural and food products is emphasized in all strategic documents as a threat. Reduction of this deficit, and thus achieving a greater degree of self-sufficiency, remains a priority. In this context, it is important to consider the position of individual subsectors in foreign trade, and to determine the degree of self-sufficiency in certain agricultural products, including fruits.

A competitiveness study showed that the fruit and vegetable sector is one of the three most competitive sectors in $\mathrm{BiH}$, and that export is constantly increasing, both on the world and EU markets (MEORS RS, 2017). In BiH, the plum is the most represented fruit species, both by number of trees and by production volume, followed by apple and pear. Plum is traditionally the dominant in $\mathrm{BiH}$ and is mainly used for the production of plum brandy (rakija), while a small part is processed, dried or consumed fresh. Apple comes after the plum by volume of production. The apple is mostly consumed fresh. The pear, which is also a traditional fruit, is usually finalized through processing into pear brandy. Taking into account that a considerable part of apple, pear and plum are used in processing, for the estimation of self-sufficiency and per capita consumption, the production of these types of fruits is converted to the quantities used for human consumption, i.e. use in the fresh state.

Fruit production as plant production is characterized by a number of comparative advantages in relation to other branches of agriculture. In addition to employment opportunities for large numbers of workers, fruit can be attractive not only for farmers, but for the enterprising people of all other occupations (Kljajić et al., 2015). 
Fruit production was reduced by as much as 35\% in 2017 compared to production from the previous year, due to extreme drought (MOFTER, 2018). Unlike some other countries, there is no separate recording of extensive and intensive fruit orchards in $\mathrm{BiH}$. Likewise, the production of all large fruit types is still calculated by fruit tree, not per area unit. Fruit yields in $\mathrm{BiH}$ are not expressed per area unit, but per fruit tree. Statistics of production volume by number of fruit trees/productive trees is certainly not the best indicator of production trends and do not allow comparability with other countries in terms of fruit production productivity. Whole $\mathrm{BiH}$, cover a large part of its food needs by import, and has a foreign trade deficit. Bosnia and Herzegovina is one of the major raspberry exporters in the world and holds a high place on the world market. There is a surplus in the export of plums, raspberries and cherries, and also in the export of forest fruits (Šaljić et al., 2018).

Grgić and associates (2011) states that production and consumption balances provide information on the supply and demand of agro-food products, the level of selfsufficiency and consumption of food per capita. Vlahović and associates (2005) were analyzing fruit consumption in Serbia and Montenegro, and conclude that fruit consumption depends mainly on the consumer's standard of living and that the socalled "natural" consumption, from own production, is increasing, thus eliminating market dependence. Gavrila and associates (2014) are citing that self-sufficiency as an important indicator in food security assessment. This reflects the coverage of the population's consumption needs by domestic production. As the self-sufficiency level is lower and it is accompanied by yearly fluctuations, the supply is volatile and the country's vulnerability increases.

In 2010, the Ministry of Foreign Trade and Economic Relations of BiH (MOFTER, 2010) has made production and consumption balances, as well as a degree of selfsufficiency for a certain number of agri-food products. Thus, estimation was made for the apple, where the level of self-sufficiency was $74.30 \%$ and consumption per capita was $15.5 \mathrm{~kg}$. Kolodziejczak (2018) states that among EU-13 countries, only Polish agriculture has reached agricultural production comparable to EU-15 level. As a whole, the EU-28 and its "old" part, the EU-15, and the "new" part (EU-13) are now and they will be self-sufficient in food production until 2080, except in the case of fruit. About 2/3 of fruit demand will be covered by EU domestic production over the forecasted period, while the missing quantities will have to be imported. German Federal Ministry of Food and Agriculture (BMEL, 2014) presents data on the state of horticulture in this country and states that the consumption of apples per capita is $25 \mathrm{~kg}$ and that apples are the most favorite fruit, pears consumption is 2.3 $\mathrm{kg}$ and plums (mirabel) $1 \mathrm{~kg}$, and in that case domestic fruit production does not satisfy the domestic demand (67.8 kg fruit per capita). Hambrusch and Quendler 
(2009) state that during the last ten years in Austria the overall consumption of fruits and vegetables per capita has increased to $94 \mathrm{~kg}$ and $106 \mathrm{~kg}$, respectively, whereas regional and organic production have gained increasing importance.

Consumption and sale of fresh products requires products of superior quality, and the level of quality that will achieve the best price on the market. Customers usually buy small quantities of fresh fruits or vegetables, and those are quantities for one or several days (Šaljić et al., 2018). According to the EUROSTAT survey in 2017, one in four people (27\%) in the EU ate fruit at least twice a day, $37 \%$ of the EU population ate fruit once a day, and the remaining 36\% ate fruit less frequently, or not at all, during the week (EUROSTAT, 2019). According to the same source, about $64 \%$ of EU residents eat fruit every day while e.g. this percentage is $46 \%$ in Croatia and $85 \%$ in Italy. Despite extensive promotion of worldwide consumption of fruits and vegetables, per capita consumption is estimated at 20 to 50 percent less than the minimum recommended level of 400 grams or five servings of 80 grams per day (FAO, 2017).

\section{Material and Method}

The aim of this research was to identify trends in the production and consumption of the three most common types of fruit in $\mathrm{BiH}$ (apples, pears and plums) and to determine the degree of BiH's self-sufficiency in these fruit species. Methodologically, self-sufficiency in fruit production is calculated as Ostojić and Vaško (2019) did in the case of meat for the same time period and the same country. As usual, one of the problems in calculating the self-sufficiency coefficients is the reliability of the input data, since the data on the quantities of fruit produced are partly based on subjective estimates, and consumption data are more the result of expert estimation than exact surveys of consumer habits and reactions. Different relationships have been used to recalculate the quantities of fruit that are used in industry, from technological norms to their own estimations. Foreign trade is the result of the data obtained on imports and exports from the Indirect Taxation Authority database.

In the calculation of self-sufficiency balance, total production is reduced by losses and processing, because the analyzed fruits beside fresh consumption are, also, used for processing, for human and industrial consumption. During the analysis statistical agencies reduced the quantities of produced fruit by the estimated quantities consumed for processing as well as the estimated losses incurred during the product manipulation. Fruit production is the result of published statistical data on the production trend.

The number of fruit consumers is equal to the population and a constant population 
number was used for all years. Population data were obtained from the last census (3,531,159), (AS BiH, 2013).

The time period covered by the survey is 2014-2017 and the geographical area is the territory of Bosnia and Herzegovina.

The method of the research was combination desk research of literature sources and own data calculation from secondary sources.

The starting point for estimating the level of self-sufficiency is the balance:

Production + Import $=$ Consumption + Export

The assessment of the self-sufficiency level is calculated according to the following formula (FAO, 2012):

\section{Import Dependency Ratio $=$ Import x $100 /($ Production + Import - Export $)$}

not considering the initial and final stocks (Clapp, 2015-2016), which are, anyway, mutually annulled in the long run.

Estimation of the level of dependence on imports is calculated according to the formula (FAO, 2012):

Self Sufficiency Ratio $=$ Production $x 100 /($ Production + Import - Export $)$

The indicative consumption of certain types of fruit per capita is calculated according to the following formula:

Per capita consumption $=($ Production + Import - Export $) /$ Number of population

Laspeyres aggregated price index is used to understand the dynamics of import and export prices for the observed fruits. This index represents the relative change in total aggregate prices of the observed phenomena in the current period compared to the total prices in the base period of observation, assuming that the quantities from the base period are constant. The aggregate price index for imports and exports of fresh fruits, processed fruits and total for all three observed fruit species was calculated in the analysis. The baseline period is the initial year of analysis, i.e. 2014. Laspeyres index is calculated using the following formula (ILO, 2019):

$$
P_{L}=\frac{\sum_{i=1}^{n} p_{i}^{t} q_{i}^{0}}{\sum_{i=1}^{n} p_{i}^{0} q_{i}^{0}}
$$

whereby the symbol $p$ denotes the price and the symbol q the quantity in the current (t) or base (0) period. 


\section{Results of Research and Discussion}

Apple production in $\mathrm{BiH}$

Apple is predominantly the European continental fruit, with the largest share in total European fruit production (Vlahović, 2015). Apple is the second most produced fruit species in $\mathrm{BiH}$, with an increase of $78 \%$ in the number of apple trees over the last 10 years (Šaljić et al., 2018). The total number of productive apple trees in $\mathrm{BiH}$ ranged from 6.5 to 7 million, with average of 6.7 million (AS BiH, 2015-2018). Yields per tree varied on average between 6.8 and $13.6 \mathrm{~kg} / \mathrm{tree}$. Analyzing apple production at the $\mathrm{BiH}$ level, the largest production was in 2015. This production is slightly more than 2 times higher than in the previous year, and about 1.3 times more than the production in the next year. The average apple production was 64,403 tons. Starting exclusively from official statistical data, on average $18.24 \mathrm{~kg}$ of apples, per capita, were produced in the observed period in $\mathrm{BiH}$. However, data on the quantity of produced apples should be taken with a pinch of salt, first of all, in relation to the total amount that can be considered as commercial production suitable for processing or export, since each rural household in $\mathrm{BiH}$ has several apple trees for its own needs. According to the latest census, $\mathrm{BiH}$ had 363 thousand and Republika Srpska 141 thousand rural households, so if each household has only 5 apple trees, half of the produced apple is not traded on the market. In neighboring Croatia, today, the apple production, neither in quantity nor in quality, meets domestic demand (Cerjak et al., 2011).

Apple foreign trade

Quantitatively, in all years, $\mathrm{BiH}$ has made a negative balance between the import and export of apples (for consumption and industrial processing altogether). This deficit ranged between 14 and 22 thousand tons. It is indicative that in 2015, apple export increased by 6.1 thousand tons and at the same time apple import increased by 9.6 thousand tons. This shows that, due to insufficient production, any increase in export automatically entails, and necessarily increases, import. 
Graph 1. Foreign trade balance of fresh apples, in $\mathrm{kg}(\mathrm{BiH}, 2014-2017)$

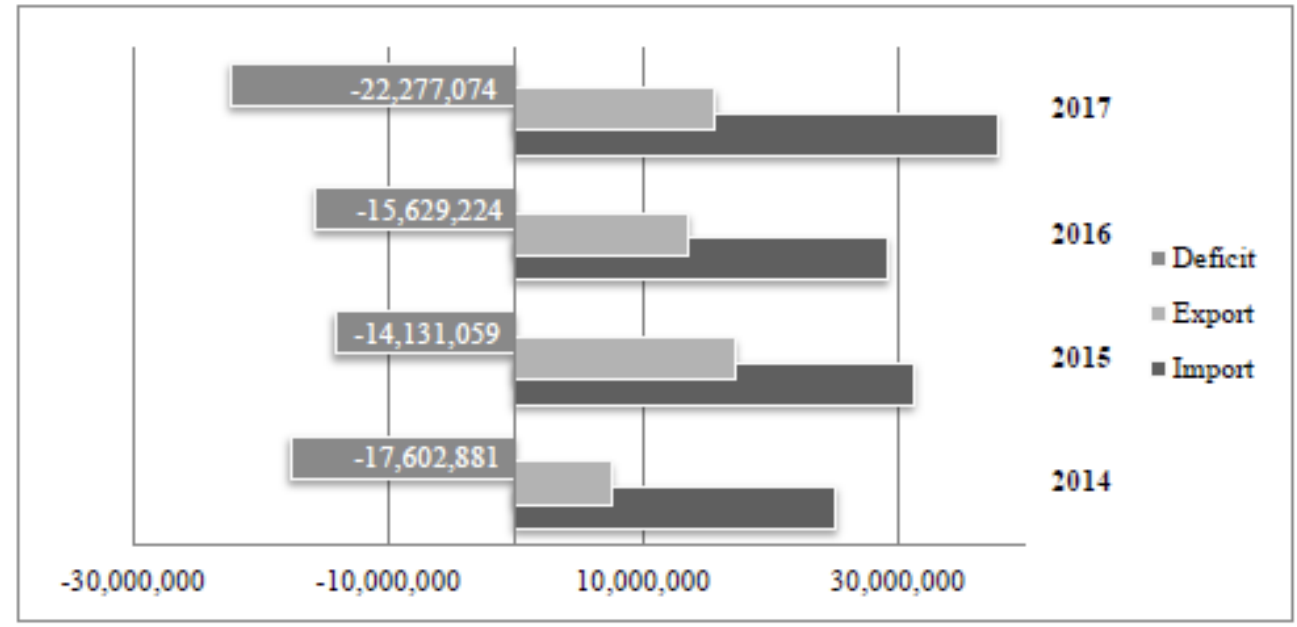

Source: Data processing by authors based on $\mathrm{BiH}$ Indirect Taxation Authority data.

Similar to the trend in fresh apples foreign trade, a constant deficit is also present in apple products, between 500 and 800 tons per year, mainly due to the import of apple juice.

Graph 2. Foreign trade balance of processed apple, in $\mathrm{kg}$ (BiH, 2014-2017)

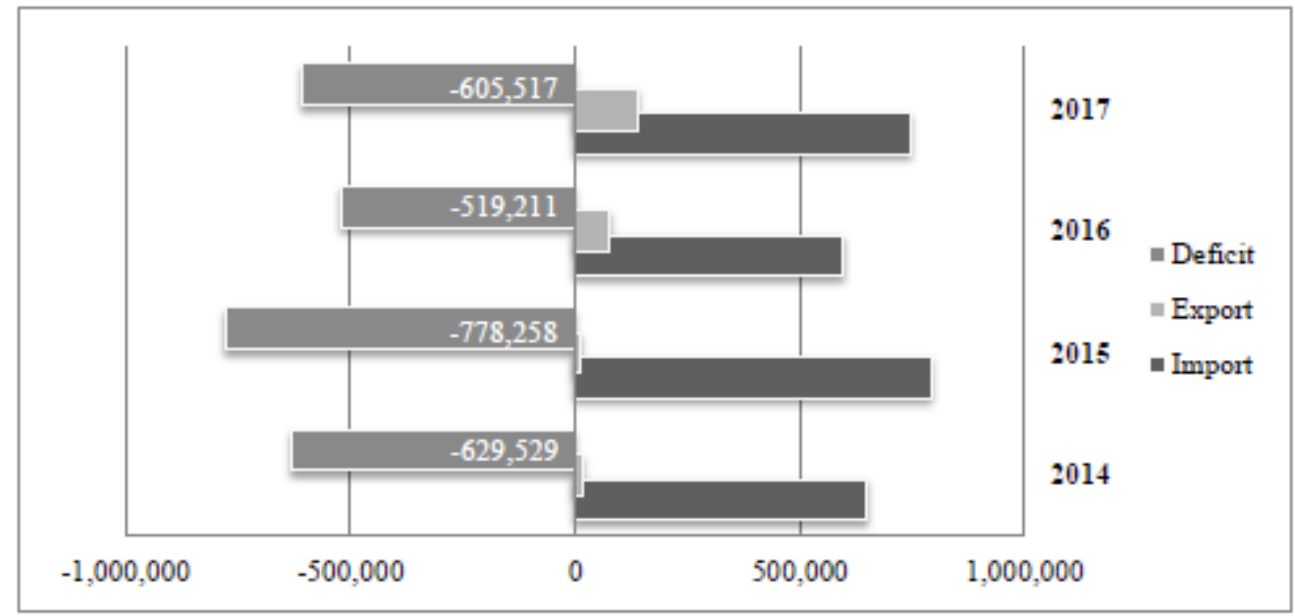

Source: Data processing by authors based on $\mathrm{BiH}$ Indirect Taxation Authority data.

In terms of value, the foreign trade balance of apple is more favorable. The initial deficit of 5.3 million KM in 2014 decreased significantly and in 2017 for the first time $\mathrm{BiH}$ achieved a financial surplus. This was certainly due to fruit export to the Russian market and higher export compared to lower import prices. Russia is the 
largest importer of apples and imports an average of 1.4 million tones, accounting for $13 \%$ of total world import (Vlahović, 2015).

Graph 3. Foreign trade apple balance, in $\mathrm{KM}^{6}(\mathrm{BiH}, 2014-2017)$

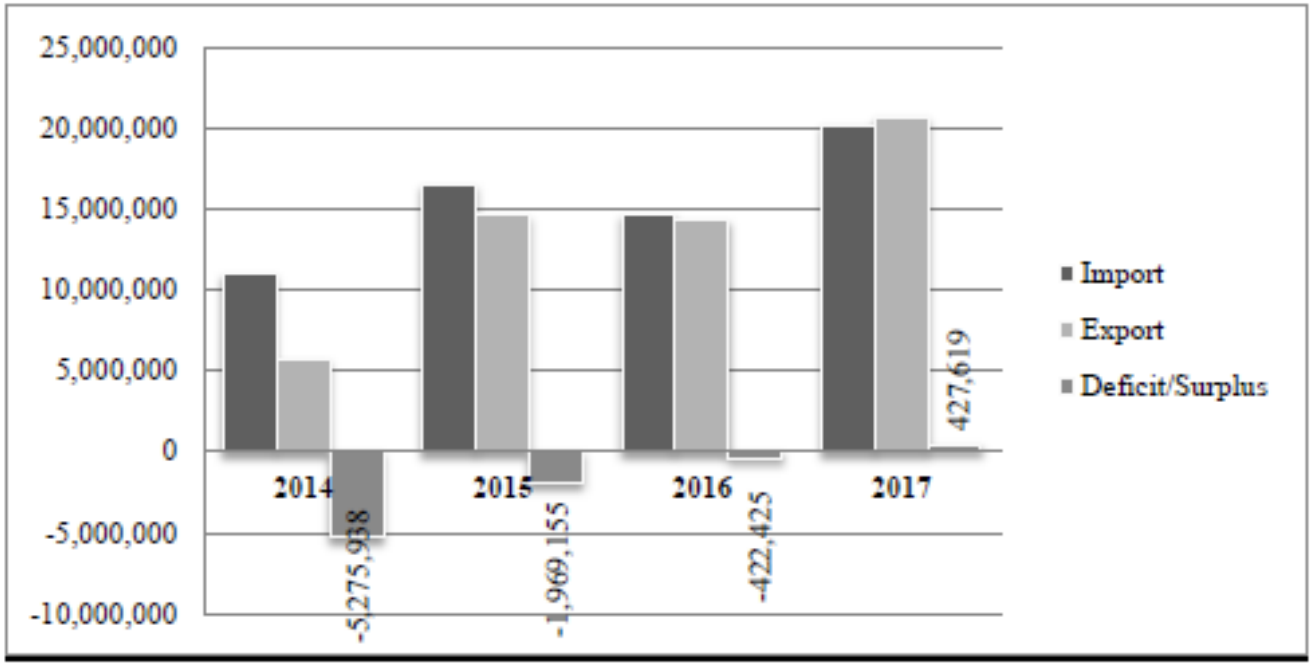

Source: Data processing by authors based on $\mathrm{BiH}$ Indirect Taxation Authority data.

The value balance and trends in the foreign trade of apple products are similar to their volume balance and they are characterized by a constant deficit.

Graph 4. Foreign trade balance of processed apple, in KM (BiH, 2014-2017)

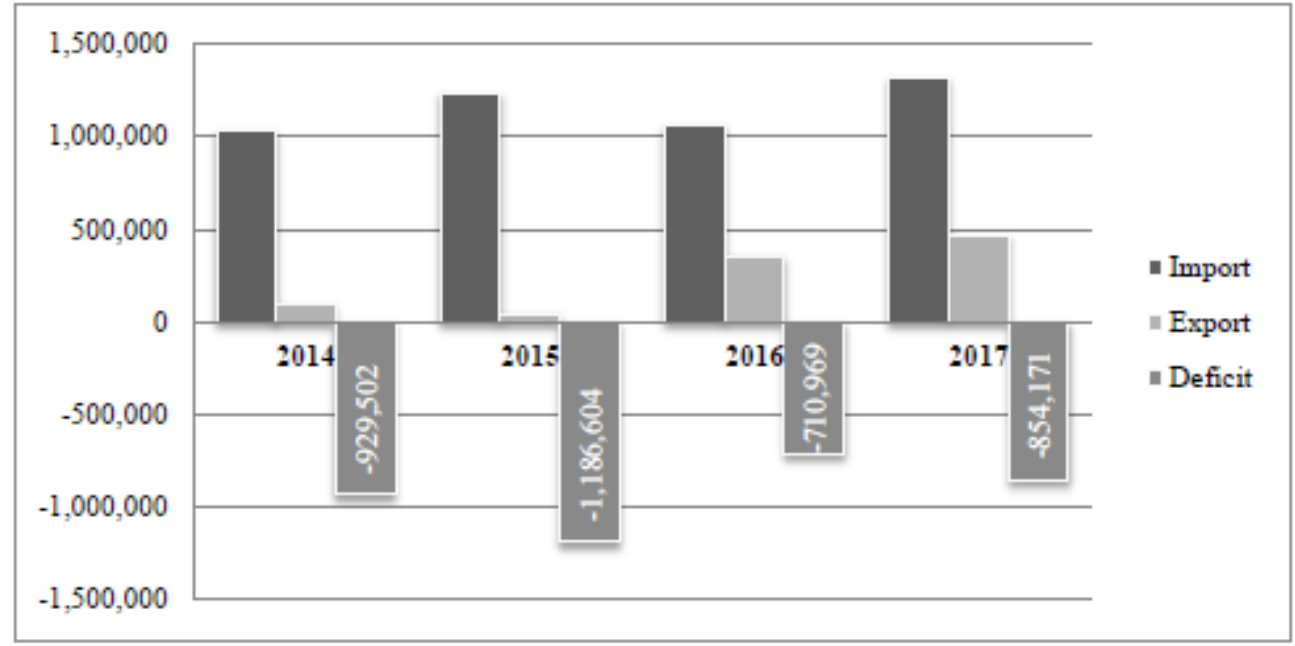

Source: Data processing by authors based on BiH Indirect Taxation Authority data.

6 Fixed exchange rate $1 \mathrm{EUR}=1.95583 \mathrm{KM}(\mathrm{CBBiH}, 2019)$. 
If we look at the apple product import structure, then it is noticeable that trade in apple juice dominates, where $\mathrm{BiH}$ is in deficit, both in terms of quantity and value. It is interesting that according to the available data, $\mathrm{BiH}$, except in 2015 , had a surplus in international trade in dried apples and there is growing tendency.

Apple self-sufficiency in BiH

The largest apple import was in 2017, around 37 thousand tones, and the lowest in 2014 when the production was, also, the lowest. If raspberries are neglected, compared to pears and plums, in terms of quantity, $\mathrm{BiH}$ mostly export apples. Bosnia and Herzegovina exported the highest quantity of apples in 2015 and the lowest in 2014. On average, about 30,925 tons of apples were imported and about 13,530 tones were exported. The worldwide consumption of apples per capita is 15 kilograms. The leading regional consumer is Europe with just over 20 kilograms (Vlahović, 2015). According to the survey results, $\mathrm{BiH}$ imported on average $8.75 \mathrm{~kg}$ of fresh apple, per capita.

Table 1. The level of apple self-sufficiency in $\mathrm{BiH}$ (2014-2017)

\begin{tabular}{|l|r|r|r|r|}
\hline \multicolumn{1}{|c|}{ Year } & \multicolumn{1}{c|}{$\mathbf{2 0 1 4 .}$} & \multicolumn{1}{c|}{$\mathbf{2 0 1 5 .}$} & \multicolumn{1}{c|}{$\mathbf{2 0 1 6 .}$} & \multicolumn{1}{c|}{$\mathbf{2 0 1 7 .}$} \\
\hline Production (t) & 44,795 & 91,471 & 69,092 & 52,252 \\
\hline Import (t) & 25,185 & 31,379 & 29,223 & 37,912 \\
\hline Export (t) & 7,569 & 17,246 & 13,620 & 15,686 \\
\hline Import Dependency Ratio (\%) & 40.35 & 29.71 & 34.50 & 50.90 \\
\hline Self Sufficiency Ratio (\%) & 71.8 & 86.6 & 81.6 & 70.2 \\
\hline $\begin{array}{l}\text { Production + Import - Export - Losses - Industrial } \\
\text { Consumption - Processing (Food Products) }\end{array}$ & 51,660 & 83,652 & 68,113 & 61,938 \\
Human Consumption (t) & 14.63 & 23.69 & 19.29 & 17.54 \\
\hline Per capita consumption (kg) & & & & \\
\hline
\end{tabular}

Source: Author's own calculation.

Domestic consumption is basically higher than domestic production. Domestic consumption of apples in the observed period ranged from 51 to 83 thousand tons. According to the balance data, the average consumption of apples in the analyzed period was $18.79 \mathrm{~kg}$ per capita. Most of the apples are consumed fresh. The average level of self-sufficiency is $77.5 \%$, which indicates a deficit in this fruit species production. If the average apple consumption and the average per capita import in the analyzed period are related, it can be said that every other kilogram of apples consumed is imported $(2.15 \mathrm{~kg})$. Cerjak and associates state that apple consumption is the most influenced by substitutability for bananas, oranges and other seasonal fruits. et al.), while the apple market's self-sufficiency was 107\% (Mesić et al., 2017). 


\section{Pear production in $\mathrm{BiH}$}

Pear production averaged 20,173 tons in 2014-2015, ranging from 13,949 to 27,371 tons during the analyzed period ( $\mathrm{AS} \mathrm{BiH}, 2015-2018)$. The production of pears shows cyclical trends and the number of productive trees is about 2.5 million on average, with a slight upward trend. In 2015, when production was at its highest, so was productivity, as the smallest number of trees gave the highest production and thus gave $11 \mathrm{~kg}$ per tree. It is difficult to compare yields with other countries given the way they are expressed per tree and not per area unit. The average yield is about $8 \mathrm{~kg} /$ tree. Pears are the third-ranked fruit species in $\mathrm{BiH}$ production. Statistical production of pears shows that $5.7 \mathrm{~kg}$ of this fruit is produced per capita in $\mathrm{BiH}$. However, as with the apple, all this quantity cannot be considered as commercial production, since there are many pear trees in house backyards and their fruits are for household members only.

\section{Pear foreign trade}

In the foreign trade balance of pears, $\mathrm{BiH}$ has steadily increased, import and export at the same time. It could be said that the export was realized thanks to the import. With the exception of 2014, the deficit in terms of quantities for the analyzed period has been steadily increasing when it comes to fresh pear.

Graph 5. Foreign trade balance of pears, in $\mathrm{kg}$ (BiH, 2014-2017)

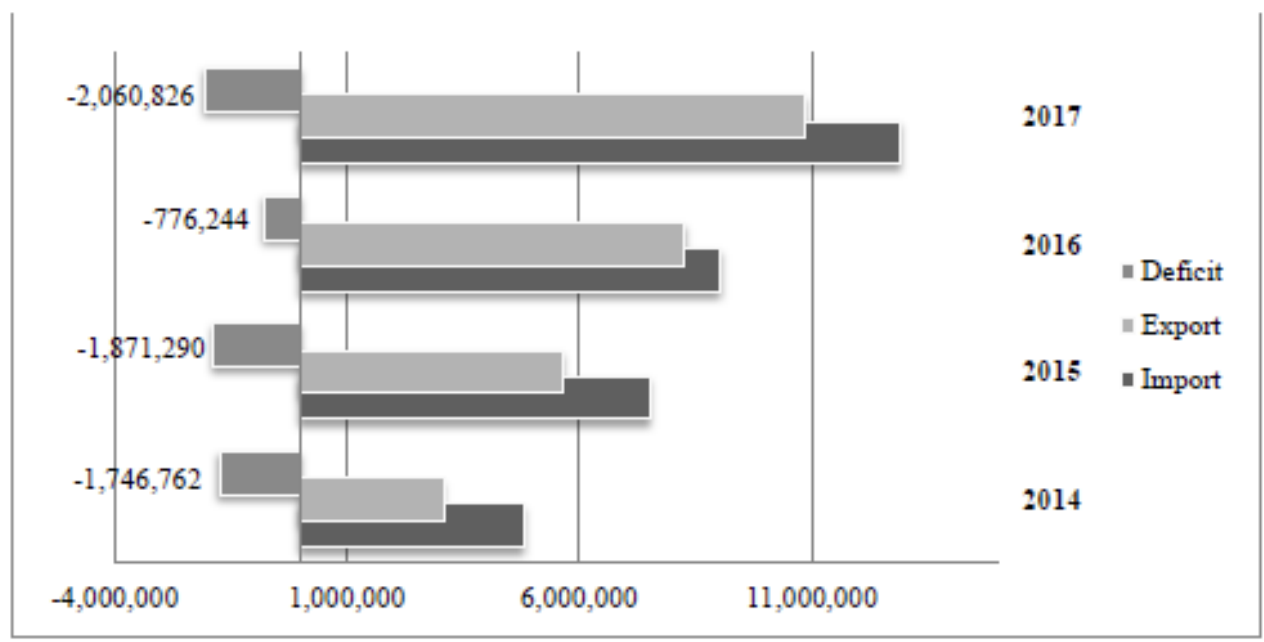

Source: Data processing by authors based on BiH Indirect Taxation Authority data.

For pear products, the imported quantity is reduced, which is the main reason for the deficit reduction. In terms of structure, the largest deficit is recorded in the import of canned pear and pear juice, and the lowest in brandy. 
Graph 6. Foreign trade balance of processed pear, in $\mathrm{kg}$ (BiH, 2014-2017)

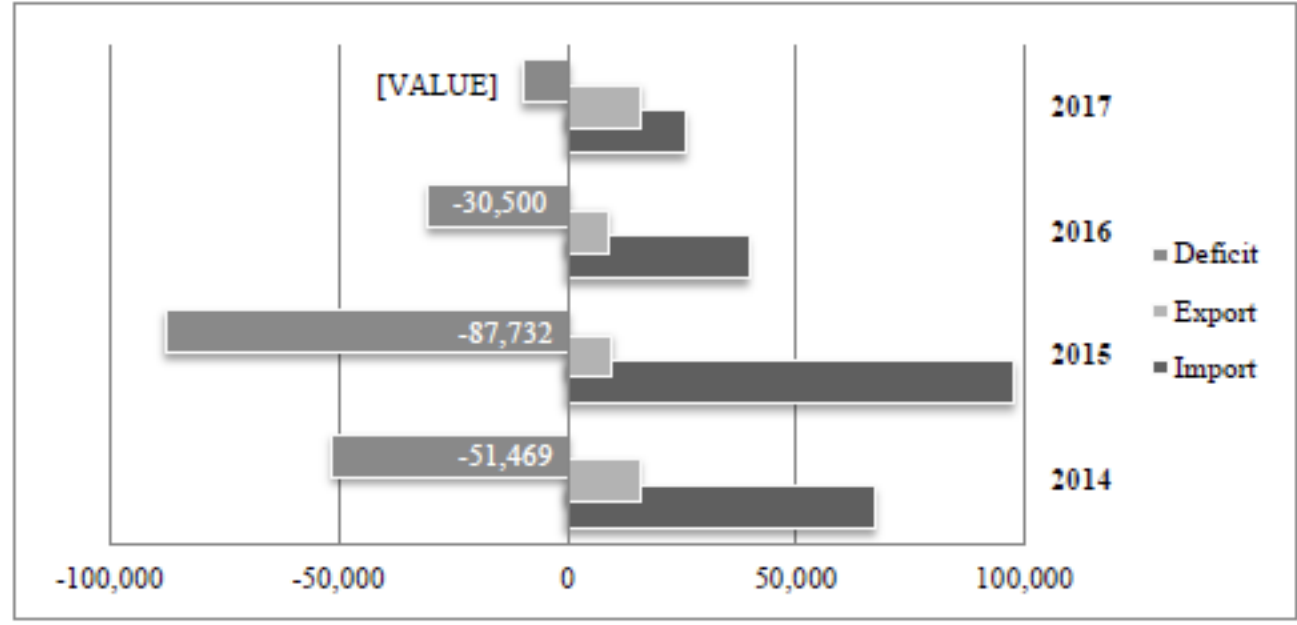

Source: Data processing by authors based on $\mathrm{BiH}$ Indirect Taxation Authority data.

In terms of value, pear exports were more valuable than imports, so a surplus was recorded in all years. The surplus in the foreign trade of pears was realized due to a more favorable relationship between (higher) export and (lower) import prices.

Graph 7. Foreign trade balance of pears, in $\mathrm{KM}$ (BiH, 2014-2017)

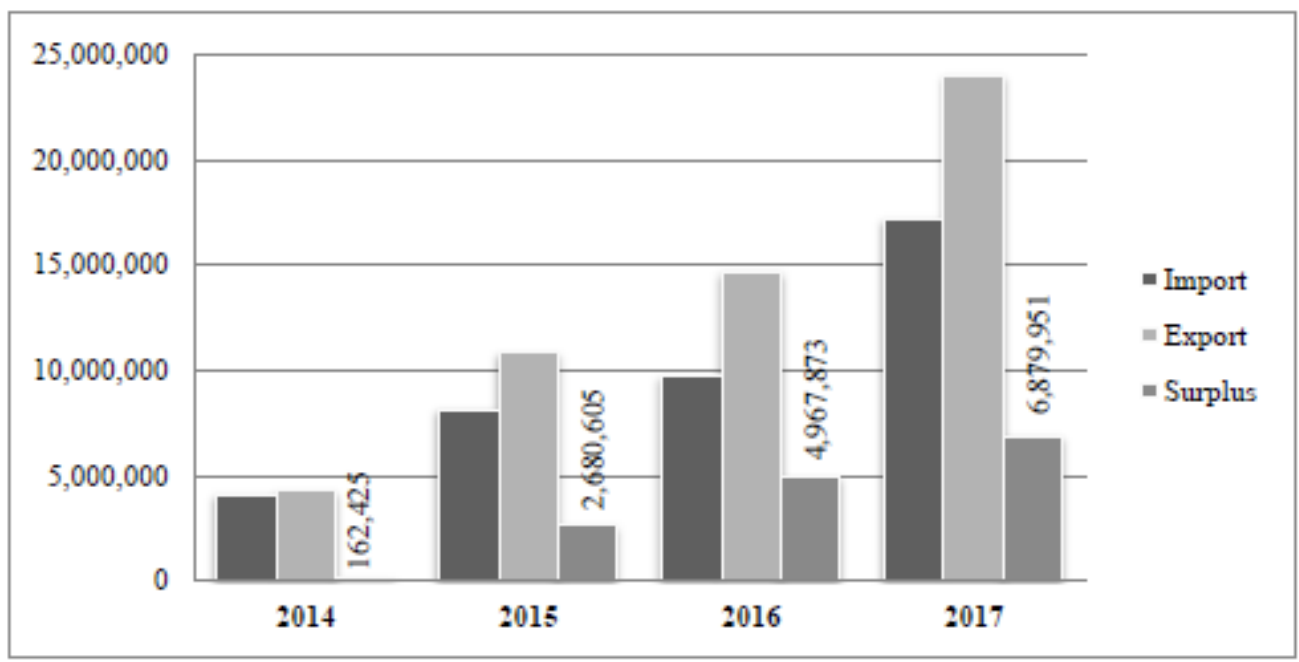

Source: Data processing by authors based on $\mathrm{BiH}$ Indirect Taxation Authority data.

For pear products, the deficit in quantity is confirmed by the deficit in value. 
Graph 8. Foreign trade balance of processed pear, in $\mathrm{KM}$ (BiH, 2014-2017)

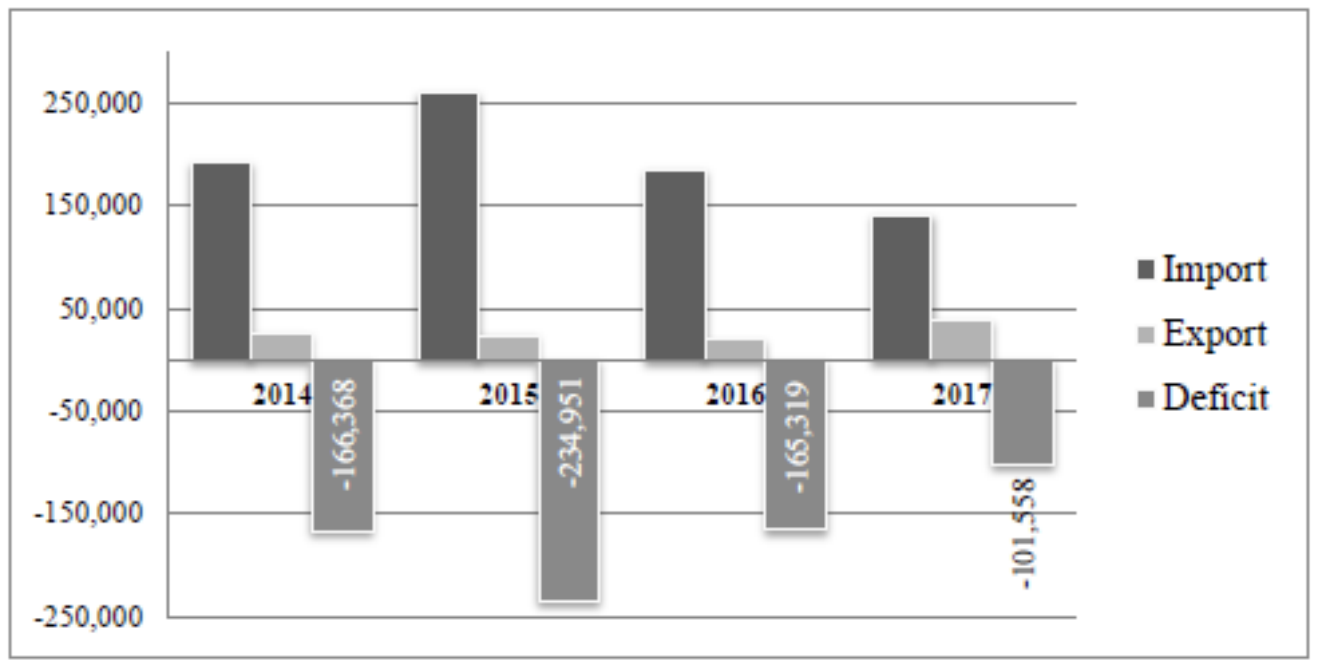

Source: Data processing by authors based on $\mathrm{BiH}$ Indirect Taxation Authority data.

Pear self-sufficiency in $\mathrm{BiH}$

A considerable part of the pear goes to industrial consumption, primarily non-food products, according to experts. Imports of pears to Bosnia and Herzegovina have intensified in the last two years, with an average of 8.5 thousand tons being imported. Export of pears has been growing steadily and it had highest value in the last year of observation where more than $70 \%$ of produced pears were exported, but still import is higher than export. $\mathrm{BiH}$ on average imported $2.43 \mathrm{~kg}$ of fresh pears per capita for the analyzed period.

Table 2. The level of pear self-sufficiency in BiH (2014-2017)

\begin{tabular}{|l|r|r|r|r|}
\hline \multicolumn{1}{|c|}{ Year } & \multicolumn{1}{c|}{$\mathbf{2 0 1 4 .}$} & \multicolumn{1}{c|}{$\mathbf{2 0 1 5 .}$} & \multicolumn{1}{c|}{$\mathbf{2 0 1 6 .}$} & \multicolumn{1}{c|}{$\mathbf{2 0 1 7 .}$} \\
\hline Production (t) & 13,949 & 27,371 & 24,003 & 15,370 \\
\hline Import (t) & 4,820 & 7,534 & 9,052 & 12,935 \\
\hline Export (t) & 3,073 & 5,663 & 8,276 & 10,874 \\
\hline Import Dependency Ratio (\%) & 30.71 & 25.76 & 36.53 & 74.21 \\
\hline Self Sufficiency Ratio (\%) & 88.9 & 93.6 & 96.9 & 88.2 \\
\hline $\begin{array}{l}\text { Production + Import - Export - Losses - Industrial } \\
\text { Consumption - Processing (Food Products) }\end{array}$ & 4,816 & 7,893 & 6,057 & 5,442 \\
Human Consumption (t) & 1.36 & 2.24 & 1.72 & 1.54 \\
\hline Per capita consumption (kg) & & & & \\
\hline
\end{tabular}

Source: Author's own calculation.

As with apples, in $\mathrm{BiH}$ more pears are consumed than produced, and as a result, the level of self-sufficiency is less than 100 . The highest level of self-sufficiency was 
achieved in 2016 (96.9\%), and the average was about 92\%. Domestic consumption in the fresh state ranged from 4 to 8 thousand tons. According to data on the average fresh pear import per capita and the average fresh pear consumption per capita, it can be seen that the market lacked 700 grams per capita of pear on average, which may be due to the present assortment of this fruit type and its benefits for fresh consumption. The pear consumption in the world is around three kilograms per capita, with the largest regional consumer being Europe (Vlahović, 2010).

\section{Plum production in $\mathrm{BiH}$}

Plum is the most popular fruit species in Bosnia and Herzegovina according to the number of trees. Plum production in $\mathrm{BiH}$ accounts for $53 \%$ of total fruit production in the country (Šaljić et al., 2018). In the fruit sector, it is a fruit species with an average of more than 12 million trees. According to available statistics, an average of 100,000 tons of plum is produced on 12 million trees. Plum is a fruit species that is also predominantly processed, according to some estimations, over $75 \%$ is processed in brandy (rakija), with a smaller proportion used in consumable or other processed form. Average yields were at $8 \mathrm{~kg} /$ tree. The highest production (131 thousand tons) was recorded in 2016 with a yield of $10.6 \mathrm{~kg}$ per tree (AS BiH, 2015-2018). Domestic production covers $99 \%$ of the market demand for this fruit. Most plums are used for brandy, and since each household has supplies of brandy from previous years, they relatively easily overcome significant fluctuations in the total plum production, which ranged from 74 to 131 thousand tons.

\section{Plum foreign trade}

The only analyzed fruit species in which $\mathrm{BiH}$ has a constant surplus (both in quantity and in value) is plum, which reached 4,000 tons in 2017. The volume of foreign trade depends more on market opportunities than on production, since the smallest exports were made in the year when production was highest (2016). Imports increased significantly in 2017, when exports, also, increased significantly, with imports growing faster than exports in terms of volume. The average annual growth rate for imports was $46.7 \%$ and for exports $26.4 \%$ (in quantity and $44.3 \%$ and $31.4 \%$ in value).

The quantities of imports and exports include prune, with $\mathrm{BiH}$ recording a steady deficit, which is increasing (in 2014 it was 162 tones and in 2017 it was 301 tones). Although not a technologically demanding or high investment process, this example shows that the development of the $\mathrm{BiH}$ food processing industry is at a low level and that fresh fruit is still predominantly exported. 
Graph 9. Foreign trade balance of fresh plums and prune, in $\mathrm{kg}(\mathrm{BiH}, 2014-2017)$

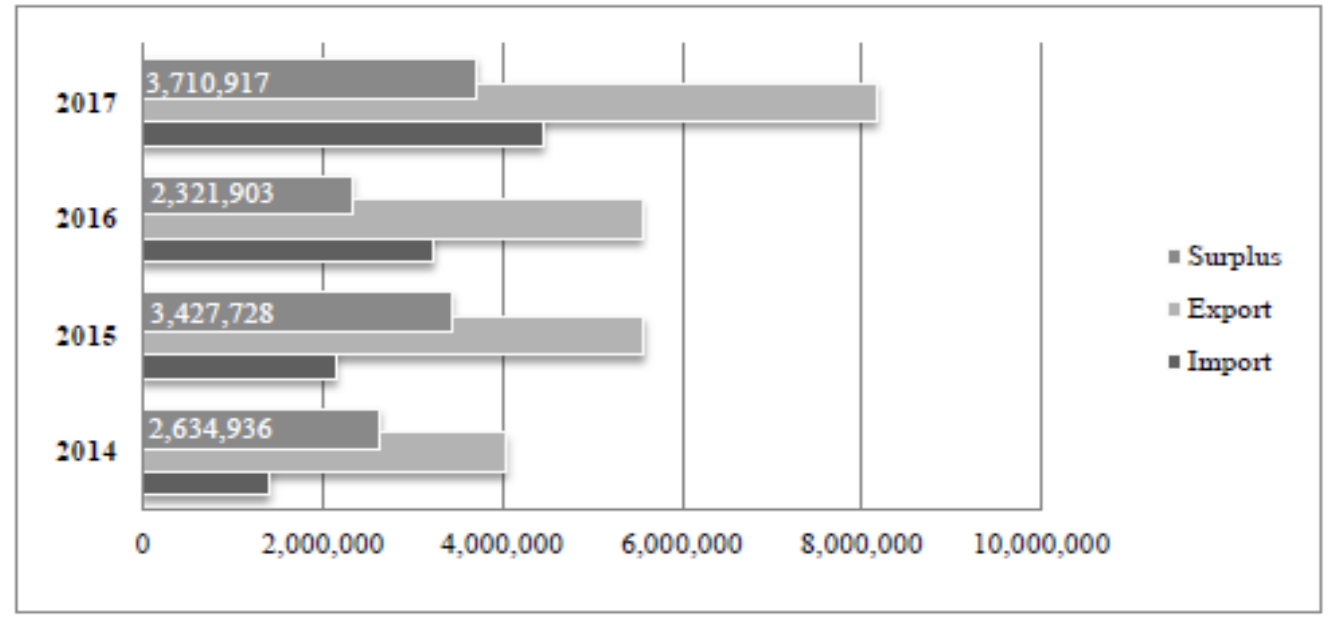

Source: Data processing by authors based on $\mathrm{BiH}$ Indirect Taxation Authority data.

$\mathrm{BiH}$ has been making surplus in processed plums in all years thanks to the export of plum brandy.

Graph 10. Foreign trade balance of processed plums, in $\mathrm{kg}$ (BiH, 2014-2017)

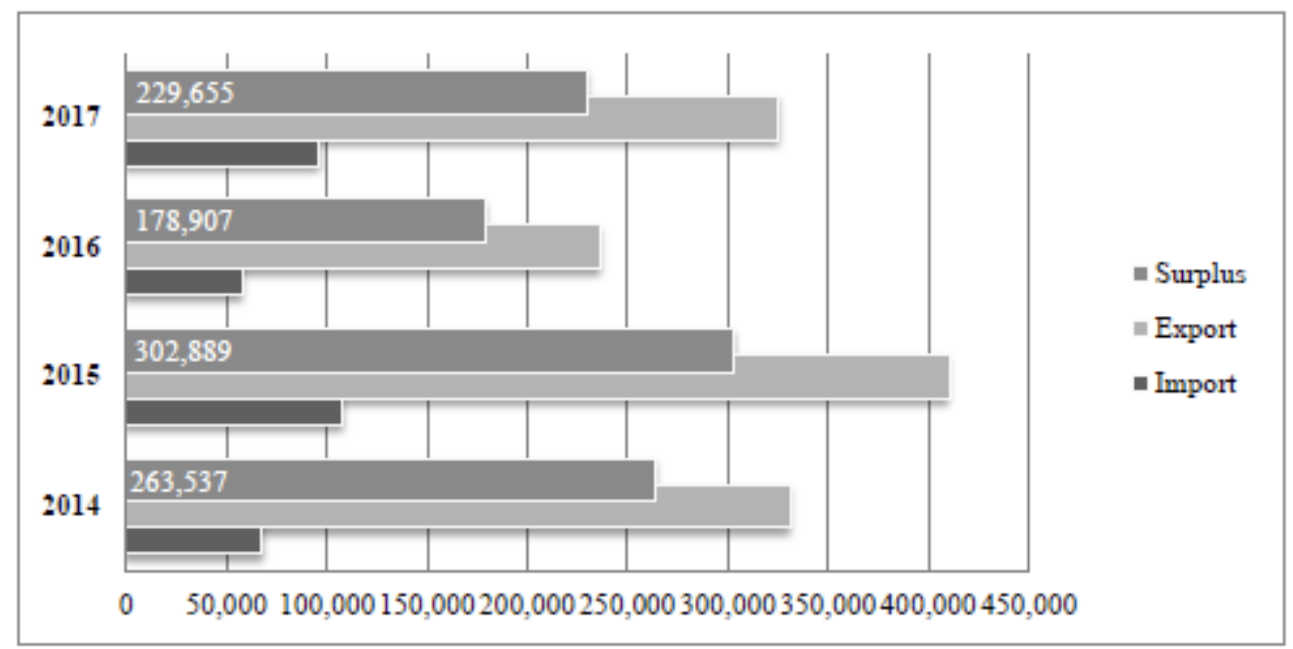

Source: Data processing by authors based on $\mathrm{BiH}$ Indirect Taxation Authority data

The value of plum exports has steadily increased by 2-3 million KM per year. Due to the stagnation of imports, the surplus in foreign trade is constantly increasing. These data on foreign trade indicate that $\mathrm{BiH}$ has a competitive advantage in the production of plums, but it should work on substitution of imported prune with domestic, since it has the necessary raw material basis. 
Graph 11. Foreign trade balance of fresh plum and prune, in $\mathrm{KM}(\mathrm{BiH}, 2014-2017)$

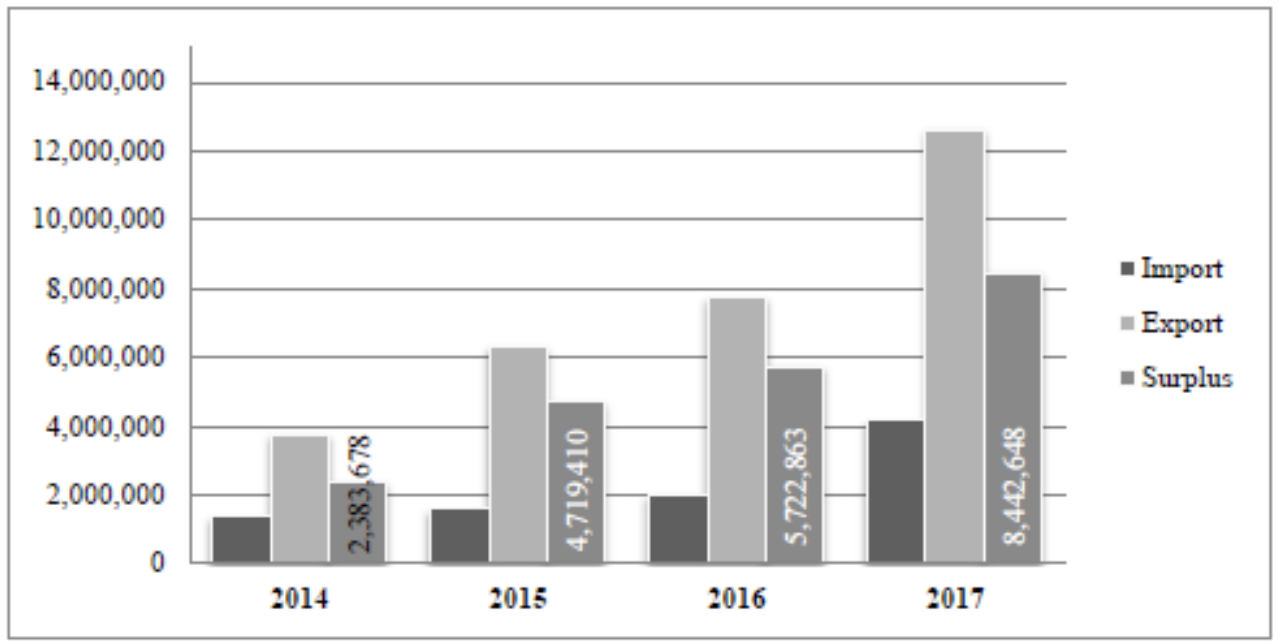

Source: Data processing by authors based on BiH Indirect Taxation Authority data.

The surplus of processed plums is realized by the export of alcoholic beverages (rakija), which ranged between 1.5 and 2.4 million KM.

Graph 12. Foreign trade balance of plums, in $\mathrm{KM}(\mathrm{BiH}, 2014-2017)$

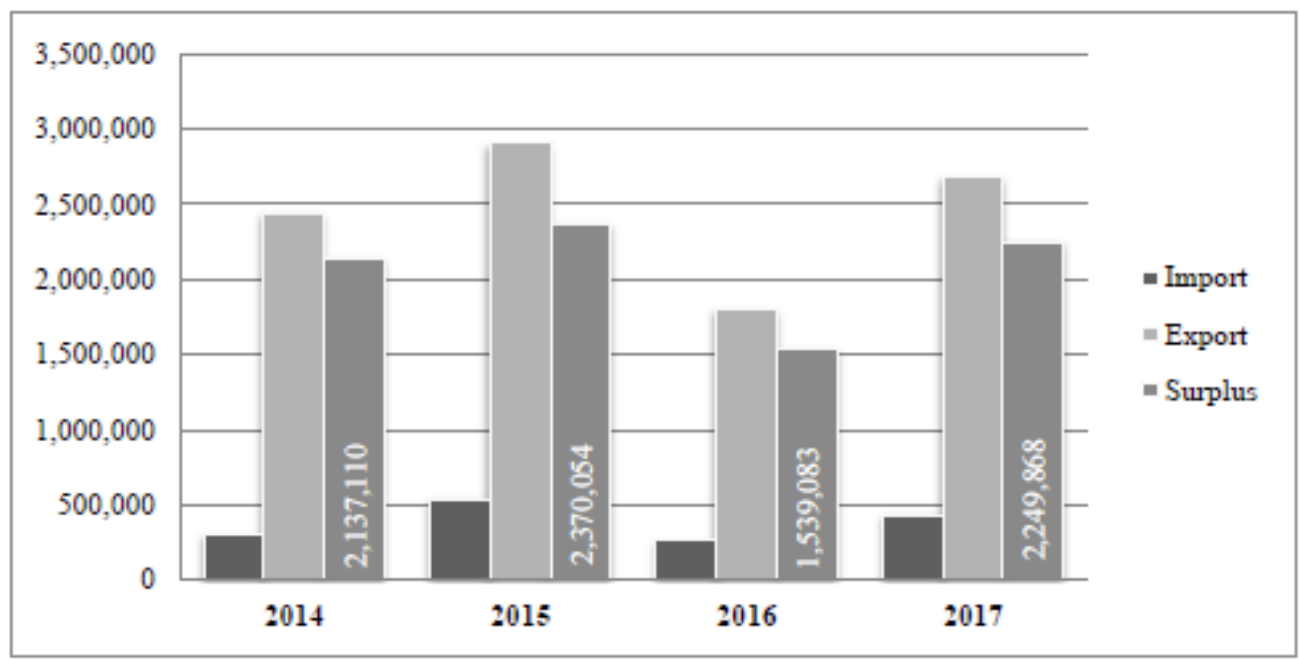

Source: Data processing by authors based on $\mathrm{BiH}$ Indirect Taxation Authority data

In addition to higher export than import, good ratio of export and import prices contribute to the favorable plum foreign trade balance. The export price was twice the import price during the whole period. 


\section{Plum self-sufficiency in BiH}

The characteristics of the plum production balance is that it is a product where Bosnia and Herzegovina has a positive foreign trade balance since more of this product is exported than imported, in terms of quantity. On average 2.8 thousand tons were imported into Bosnia and Herzegovina and 5.8 thousand tons were exported. Plum export ranged from 4.2 to $11 \%$ of total production. $\mathrm{BiH}$, which is visible from the data presented, imports small quantities of fresh plums, and on average $0.80 \mathrm{~kg}$, per capita, for the analyzed period. The lowest amount of plum was exported in 2014, and the highest in 2017. The consumption of plums in the world is at the level of one kilogram per capita per year (as fresh fruit, without products). Consumption is very difficult to quantify since plums, like other fruits, are used not only in the fresh state but also in the form of various products (Vlahović, 2015).

Table 3. The level of plum self-sufficiency in $\mathrm{BiH}$ (2014-2017)

\begin{tabular}{|l|r|r|r|r|}
\hline \multicolumn{1}{|c|}{ Year } & \multicolumn{1}{c|}{$\mathbf{2 0 1 4 .}$} & \multicolumn{1}{c|}{$\mathbf{2 0 1 5 .}$} & \multicolumn{1}{c|}{$\mathbf{2 0 1 6 .}$} & \multicolumn{1}{c|}{$\mathbf{2 0 1 7 .}$} \\
\hline Production (t) & 74,075 & 117,465 & 131,579 & 74,398 \\
\hline Import (t) & 1,411 & 2,152 & 3,233 & 4,456 \\
\hline Export (t) & 4,046 & 5,579 & 5,555 & 8,167 \\
\hline Import Dependency Ratio (\%) & 1.97 & 1.89 & 2.50 & 6.30 \\
\hline Self Sufficiency (\%) & 103,7 & 103,0 & 101,8 & 105,2 \\
\hline $\begin{array}{l}\text { Production + Import - Export - Losses - } \\
\text { Industrial Consumption - Processing (Food } \\
\text { Products) = Human Consumption (t) }\end{array}$ & 4,032 & 7,144 & 9,520 & 2,985 \\
\hline Per capita consumption (kg) & 1.14 & 2.02 & 2.70 & 0.85 \\
\hline
\end{tabular}

Source: Author's own calculation.

The estimated consumption of plums for human consumption is around 6,000 tonnes, while the per capita consumption is about $1.68 \mathrm{~kg}$. According to the balance sheet indicators, domestic fresh consumption is less than domestic production. In this connection, the level of self-sufficiency is above 100, i.e. the production surplus is realized. Similar findings were made in the study by Šaljić and associates (2018) stating that domestic production covers $99 \%$ of market demand for this fruit. The degree of self-sufficiency was $103 \%$ on average. Gavrila and associates (2014) concluded during analysis of fruit self-sufficiency in Romania that the only product that can cover consumption needs from domestic production is plum, taking into account the growing trend of consumption. In case of apple, domestic production can cover consumption until 2017. 


\section{Group fruit import and export price indices}

During the analysis of import and export price data using the Laspeyres index following results were obtained. The dynamics of aggregate price movements for all observed fruits and all observed groups imported in and exported from $\mathrm{BiH}$, shows that prices of these three fruit species in most cases increased.

Table 4. Aggregate price indices according to Laspeyres

\begin{tabular}{|c|c|c|c|c|c|c|}
\hline \multirow{2}{*}{ Year } & \multicolumn{2}{|c|}{ Fresh fruits } & \multicolumn{2}{c|}{ Processed fruits } & \multicolumn{2}{c|}{ Total fruits } \\
\cline { 2 - 7 } & Import & Export & Import & Export & Import & Export \\
\hline 2015. & 118,14 & 122,03 & 100,08 & 95,38 & 116,57 & 116,49 \\
\hline 2016. & 113,20 & 137,93 & 116,66 & 102,94 & 110,74 & 127,15 \\
\hline 2017. & 127,87 & 166,84 & 119,19 & 110,36 & 124,08 & 151,86 \\
\hline
\end{tabular}

Source: Author's own calculation.

The prices of all observed fruit species and groups experienced a price increase with the exception of the export price of processed fruits in 2015, when the price decrease was 4.62\%. Import prices (2015) for this product group were stagnant. It is also noticeable that export prices of processed fruits have slower growth than import prices. In 2017, this group of products saw a smaller increase in export prices than import prices compared to 2014. Positive and promising is that the dynamics of changes in export prices for fresh fruits are more pronounced than the dynamics of changes in import prices. In 2016, the price increase was less than the increase in 2015 compared to 2014. When looking at the aggregate price indices at the overall level, then in 2015 it is evident that the aggregate indices of the prices of imports and exports were almost equal. A particularly high price jump is in the last year of observation, regardless of whether it is import or export prices.

\section{Conclusion}

Most of the fruit trees in $\mathrm{BiH}$ are owned by family agricultural holdings, which are not obliged to keep records of production and to report on this basis, so the data on quantities of produced fruit are based on estimates of municipal estimators who do not have reliable sources for this. Therefore, the conclusions drawn about the quantities of fruit produced are "hostages" of questionable data of the realized production. Based on the established data on fruit production and data from the Indirect Taxation Authority on the export and import of fruits, projections of production and consumption have been made and an assessment of the degree of BiH's selfsufficiency in fruit has been evaluated. The volume of apple production dynamics has a tendency to decline from 2015 to the end of the analyzed period. The pear shows oscillations in production with rising and falling from year to year, while the plum 
shows a tendency to grow until 2017. The surplus in foreign trade in plums indicates that $\mathrm{BiH}$ has a competitive advantage in the production and trade of plums, with the need to work on the substitution of imported prune with domestic, since $\mathrm{BiH}$ has the necessary raw material base. For pears, the degree of self-sufficiency was $90 \%$ on average, with very small share in fresh consumption. Fresh pear had a positive foreign trade balance, while quantitatively showed a deficit in international trade, while pear products had a deficit on both parameters. During the whole observed period, the apple had a deficit in both observed parameters (fresh and processed, quantitative and value). Based on consumption estimates and production data, it is observed that the plum has significantly higher domestic production than domestic fresh consumption during the whole period, and the balance is established by using a considerable part of this product in processing for the production of brandy. The aggregate price movement index shows that prices increased slightly more than in 2014, both in import and in export. In 2016, the dynamics of import price growth was the lowest compared to 2014, compared to the other two observed years. The dynamics of total changes in export prices also showed an upward trend compared to 2014 with the exception of 2015 for processed fruits and the growth of these total prices is more intense than the total prices of imports.

\section{References}

1. AS BiH (2013). Popis 2013. Agencija za statistiku BiH(AS BiH), Sarajevo, Bosnia and Herzegovina, available at: www.statistika.ba/, retrieved at: 21.08.2019.

2. AS BiH (2015-2018). Godišnja saopštenja o proizvodnji voća, maslina i grožđa (za period 2014-2017). Agencija za statistiku BiH (AS BiH), Sarajevo, Bosnia and Herzegovina.

3. Clapp, J. (2015-2016). Food Self-sufficiency and International Trend: A False Dichotomy. Food and Agriculture Organization of the UN (FAO), Italy, Rome, available at: www.fao.org/3/a-i5222e.pdf

4. Clapp, J. (2017). Food self-sufficiency: Making sense of it, and when it makes sense. Food Policy, 66: 88-96.

5. Cerjak, M., Vrhovec, R., Vojvodić, M., Mesić, Ž. (2011). Analyses of the Croatian apple market. In: $46^{\text {th }}$ Croatian and $6^{\text {th }}$ International Symposium on Agriculture, Proceedings, Opatija, Croatia, pp. 311- 314.

6. Thomson, A., Metz, M. (1998). Implications of Economic Policy for Food Security: A Training Manual. Training Materials for Agricultural Planning no. 40, Food and Agriculture Organization of the UN (FAO), Italy, Rome. 
7. FAO (2012). FAO Statistical Pocketbook 2012: World Food and Agriculture. Food and Agriculture Organization of the UN (FAO), Italy, Rome, available at: www.fao.org/docrep/016/i2493e/i2493e.pdf, retrieved at: 12.9.2018.

8. FAO (2017). Fruit and Vegetables for Health Initiative. Food and Agriculture Organization of the UN (FAO), Italy, Rome, available at: www.fao.org/3/ai6807e.pdf, retrieved at: 28.8.2019.

9. BMEL (2014). Horticulture in Germany Facts and Figures. Federal Ministry of Food and Agriculture (BMEL), Bonn, Germany, available at: www.bmel. de/SharedDocs/Downloads/EN/Publications/HorticultureGermany-Brochure. pdf? blob=publicationFile, retrieved at: 21.8.2019.

10. Gavrila, V., Kruzslicika, M., Chiritescu, V. (2014). Fruit sector - self-sufficiency or deficit? Lucrari Stiintifice, Seria I, Facultatea De Management Agricol, 15(1):171-176.

11.Grgić, I. Franić, R., Cerjak, M., Mikuš, O., Hadelan, L., Mesić, Ž., Zrakić, M., Bokan, N. (2011). Praktikum iz agroekonomike/Practicum in agricultural economics. Agronomski fakultet Sveučilišta u Zagrebu, Zavod za agrarnu ekonomiku i ruralni razvoj, Zavod za marketing u poljoprivrede, Zavod za menadžment i ruralno poduzetništvo, Zagreb, Hrvatska.

12.Hambrusch, J., Quendler, E. (2009). A partial analysis of the fruit and vegetable sector in Austria. In: 83 ${ }^{\text {rd }}$ Annual Conference of the Agricultural Economics Society (AES), 30 ${ }^{\text {th }}$ March to $1^{\text {st }}$ April 2009, Dublin, Ireland, pp. 1-12, available at: https://ageconsearch.umn.edu/record/51055? $\ln =\mathrm{en}$

13.ILO (2019). Consumer Price Index (CPI). International Labor Organization (ILO), Genève, Switzerland, available at: www.ilo.org/public/english/bureau/ stat/guides/cpi/index.htm\#manual retrieved at: 30.8.2019.

14.Kljajić, N., Cvijanović, D., Arsić, S. (2015). Potentials and analysis of the primary crop cultivation in the municipality Pecinci. Ekonomika, 61(4):57-68.

15.Kolodziejczak, M. (2018). Food self-sufficiency in EU countries: An attempted projection to 2080. In: 27 $7^{\text {th }}$ International Scientific Conference, Agrarian perspectives XXVII, Food safety food security, September 19-20 ${ }^{\text {th }}$, Proceedings, Czech University of Life Sciences, Faculty of Economics and Management, Prague, Czech Republic, pp. 136-143.

16.Mesić, Ž., Jezidžić, A., Tomić, M., Hadelan, L. (2017). Structure of the apple supply chain and analysis of relationship between supply chain members. Glasnik zaštite bilja, 61(5):14-23.

17.MEORS RS (2017). Investiciono profil: Sektor voća i povrća Republike Srpske. Ministarstvo za ekonomske odnose i regionalnu saradnju Republike Srpske (MEORS RS), Banja Luka, BiH. 
18.MOFTER (2018). Godišnji izvještaj iz oblasti poljoprivrede, ishrane $i$ ruralnog razvoja Bosne i Hercegovine za 2017. godinu. Ministry of Foreign Trade and Economic Relations of Bosnia and Herzegovina (MOFTER), Sarajevo, $\mathrm{BiH}$, available at: www.mvteo.gov.ba/attachments/bs_Home/ Ostale stranice/Poljoprivreda, prehrana, \%C5\%A1umarstvo i ruralni razvoj/ Izvje \%C5\%A1taji za poljoprivredu, prehranu, \%C5\%Alumarstvo, ruralni razvoj_12022019 Godisnje izvjesce iz_oblasti_p_i_i_r_r BiH_za 2017 godinu bosanski jezik.pdf, retrieved at: 21.8.2019.

19.MOFTER (2010). Proizvodno-potrošne i vanjskotrgovinske bilanse za 2009. godinu / Production and Consumption and Foreign Trade Balances for 2009. Ministry of Foreign Trade and Economic Relations Bosnia and Herzegovina (MOFTER), Sarajevo, BiH.

20.Ostojić, A., Vaško, Ž. (2019). Projections of self-sufficiency of Bosnia and Herzegovina in basic types of meat. In: Sustainable agriculture and rural development in terms of the Republic of Serbia strategic goals realization within the Danube region: Sustainability and multifunctionality, 13-14 ${ }^{\text {th }}$ December 2018, Proceedings, Institute of Agricultural Economics, Belgrade, Serbia, pp. 50-67.

21.Šaljić, S., Numanović, A., Nippard, D., Sarajlić Mebarki, E., Midžić, Dž. (2018). Razumijevanje ponašanja potrošača u kategoriji proizvoda od voća i povrća: Koji su zahtjevi potrošača koje domaći proizvodi ne ispunjavaju. Market Makers and Valicon d.o.o., Sarajevo, BiH, p. 74, available at: www.zeda.ba/ wp-content/uploads/2018/11/VALICON-RAZUMIJEVANJE-PONASANJAPOTROSACA.pdf, retrieved at: 28.8.2019.

22.Vlahović, B. (2015). Tržište agroindustrijskih proizvoda - specijalni deo / Market of agro-industrial products - Special part. Univerzitet u Novom Sadu, Poljoprivredni fakultet, Novi Sad, Srbija.

23.Vlahović, B. (2010). Market of agricultural products. University Novi Sad, Faculty of Agriculture, Novi Sad, Serbia.

24.Vlahović, B., Radojević, V., Tomić, D. (2005). Fruit consumption change in Serbia and Montenegro. Economics of Agriculture, 52(1):1-9.

25.EUROSTAT (2019). Daily consumption of fruit in the EU. EUROSTAT, Luxembourg, available at: https://ec.europa.eu/eurostat/web/products-eurostatnews/-/DDN-20190401-1?inheritRedirect=true, retrieved at: 28.8.2019.

26.CBBiH (2019). Fixed exchange rate of $E U R=K M$. Central Bank of Bosnia and Herzegovina (CBBiH), Sarajevo, Bosnia and Herzegovina, available at: https:// cbbh.ba/CurrencyExchange/, retrieved at: 21.8.2019. 